\title{
USAGE OF COLORS IN TV COMMERCIALS: CROSS-INDUSTRY ANALYSIS OF MASS MEDIA COMMUNICATIONS
}

The aim of this study is to analyze the differences in color schemes in TV commercials across different product categories. The study answers the question of whether advertisers in different industries use specific color schemes to promote their company or products in TV commercials and if they follow the general recommendations for using colors in marketing communications. The research sample consists of 200 video adverts proportionally representing the commercials aired in six major product categories in the Czech Republic in 2016. The results indicate there is no statistically significant difference in the usage of colors between the product categories. Nevertheless, the advertisers in the Czech Republic generally follow the color scheme recommendations suggested by the theory.

Keywords: color content, commercials, television, mass media communication

\section{Introduction}

Color plays an important role in marketing communications. It helps to create a company or product identity, enhances brand recognition [1, 2], its memorization [3] and trust [4], attracts consumer attention [5,6], shapes consumer perception [7] and initiates purchase intentions $[3,8,9]$. As a prominent factor, color also affects advertising effectiveness [10,6] and recall [11]. Color also influences human emotions [12] and expresses customer personality [13]. To support customer self-expression, most products are offered in various colors [5]. The color subconsciously shapes consumer behavior and induces different motivations [14] - i.e., if the brand is familiar to the customer, they recall their own experience with the brand; however, if the consumer does not know the brand, they recall their associations with the color [5].

Each color has a different significance and consumer color preference also differs in various product categories [5]. The actual color itself can also affect the association of a product with a particular category $[1,15]$. There is also a difference in associations triggered by different products with the same color [3]. Therefore, advertisers must carefully select an appropriately assigned color scheme for a particular product category to make the product desirable $[16,17]$.

In general, cool colors (blue, green and violet) are preferred over warm colors (red, yellow and orange) [11]. Blue and green are recommended functional products needed to solve or prevent problems while red is a good color for sensory-social products used for self-expression, pleasure, and social approval [1]. For example, financial services are often associated with blue and green [1]; health foods with blue, green and yellow; toys with red, yellow, green and blue; cosmetics with pink [16]. Bright and cool colors seem to be habitual for the jewelry industry and bright and warm colors for children's products [9]. Beige is preferable for furniture, carpets, and paint [3]. Electronics are mostly colored black or silver, and gardening products are green [14]. Most cars are sold in black, white, red, blue and gray colors [3]. Red color is often used in the fast-food market to stimulate consumer appetites [9]. Red is also a very popular color in casinos [3], dark and warm colors are popular in night clubs, although dark and cool colors are popular in classy restaurants [9]. The color of food may help consumers to identify the flavor [16] plus the color can influence time perception when waiting [9] or spending time in the store. Gray is considered as neutral [8] and is more appreciated by men, while women prefer pink [18]. White is related to neutrality, cleanliness, and trust and in contrast, black represents modernity, style, and professionalism [19] but is also neutral. Nevertheless, black, brown, and red are sad colors while blue, orange and yellow are happy colors [9]. Brown is associated with nature [5] and environmental quality [19].

However, there is a difference between a customer's response to an individual color itself and to a product of a particular color [6]. The customer's favorite color may also have a different impact when deciding on products with high involvement [3]. For

\footnotetext{
* Daria Gunina, Tomas Kincl, Sabina Suldova

University of Economics, Prague, Faculty of Management, Jindrichuv Hradec, Czech Republic

E-mail: daria.gunina@vse.cz
} 
products with high involvement - e.g. a car or a furniture - the customers' decision is less influenced by their color preference, but rather by usual or common/expected colors associated with the product. Color combinations also evoke diverse customer reactions than just one isolated color. Therefore, marketers must carefully select the color schemes when promoting company products or the company itself.

The impact of color on various marketing activities has been examined in many previous studies. This paper focuses on the impact of color in advertising. Most developed countries suffer from advertising clutter and mass media proliferation [20, 21]. Even if the digitalization of mass media allowed more precise profiling of TV (television) channels, advertisers still do not fully utilize targeted mass media communication strategies and would rather take an undifferentiated approach [22]. In the cluttered advertising environment where customers are prone to advertising overload, a careful choice of a proper color scheme influences the first impression and eases delivering the marketing message [15] By using the right color scheme, companies can differentiate from their competitors [16, 9], enhance brand awareness, assign their product to the corresponding product category, and better target their specific audiences [5].

The motivation of this paper is to contribute to this current and resonating debate and to analyze the differences in color schemes in TV commercials across different product categories.

\section{Research design and methodology}

To answer the research question of whether there is a difference in color schemes used in TV commercials across different product categories, we analyzed the selected TV commercials aired in the Czech Republic in 2016 and used two applications: the Movie Barcode Generator [23] and the Color Extraction app provided by MulticolorEngine [24].

The commercials belong to various product categories (according to the classification NACE - Statistical Classification of Economic Activities in the European Community) - based on the monitoring data provided by Nielsen Admosphere, a. s. Categories that represented over $90 \%$ of commercials aired in the Czech Republic in 2016 are C - Foods, Drinks, D - Textile, Clothing, Leather, Shoes, E - Other Manufacturing Industry, L - Information and Communication Activities, M - Finance and Insurance, and T - Cultural, Amusement and Recreation Activities. The overview of all categories included in the analysis is in Table 1.

To select the video adverts for the analysis, we used stratified sampling where the strata reflected the number of ads in NACE categories in the whole population (ads aired in Czech Republic in 2016). Within each strata, the adverts were randomly selected from the top $20 \%$ of the largest advertisers in each NACE category. The research sample contains 200 video adverts (see
Table 1) and all commercials were downloaded from youtube.com in the highest quality available. The list of all analyzed advertisements is included in Appendix A.

Each video of an advert was processed by the Movie Barcode Generator. The software divides the video into 1000 frames. Each frame is represented by a column 1 px wide. The pixels in the column embody the colors included in each frame, divided proportionally (according to the color in each frame) between 500 px. For each video of an advert, the software generates an output image of the size $1000 \times 500 \mathrm{px}$. The output image was used to analyze the color scheme of the analyzed video.

Each color scheme was subsequently analyzed by the Color Extraction software. The software extracts the color palette of the image (see Figure 1) and calculates the percentage of all colors used. The app also assigns all identified colors to the scale of 11 basic colors [25] - blue, gray, green, brown, red, violet, orange, white, yellow, pink and black. According to Singh [9] and Crowley [11], the colors were also divided into a warm group (red, orange, yellow, pink, brown), a cool group (green, blue, violet) and neutral (gray, black, white).

To compare the frequencies of colors in each category, we utilized the Chi-Square Test of Independence. The research hypothesis was formulated as:

$H_{0}$ : the representation of colors in different NACE categories are independent variables.

The Findings Chapter provides the results of the analysis; the interpretation and discussion of the results follow in the Discussion Section.

\section{Findings}

Table 2 shows the color usage in TV commercials across the analyzed NACE categories. In general, the most used colors are neutral (gray, black, and white $-45.29 \%$ ). Moreover, the cool colors (blue, green and violet $-31.03 \%$ ) are used more than the warm ones (brown, red, yellow, pink, and orange - $23.11 \%$ ).

Table 3 shows the most used colors in each of the analyzed categories (each column sorted by the colors according to their usage in video adverts). The most popular colors among all categories were gray, blue, black, brown and green. Such colors accounted for more than $80 \%$ in each category (Category $\mathrm{C}=92.76 \%, \mathrm{D}=92.7 \%, \mathrm{E}=84.7 \%, \mathrm{~L}=88.12 \%, \mathrm{M}=86.46 \%$, $\mathrm{T}=94.59 \%)$. The color ranking is very similar across the categories, even if there are some minor differences. In comparison with other categories where the most used color was gray, in C the most prominent color is brown (over $30 \%$ ). Similarly, in $\mathrm{T}$ the most protuberant color was blue (35.31\%). D was the only category where white $(6.43 \%)$ was in the top 5 most used colors. Otherwise, the color ranking appears to be similar.

To answer the research hypothesis about the independence of colors among categories, the Chi-Square Test of Independence 


\begin{tabular}{|c|c|c|c|c|}
\hline Category & Description & $\begin{array}{l}\text { Number of } \\
\text { ads in } 2016\end{array}$ & $\begin{array}{c}\text { Category } \% \text { of total } \\
\text { number }\end{array}$ & $\begin{array}{l}\text { Number of ads } \\
\text { in sample } \\
(\% \text { of total x 200) }\end{array}$ \\
\hline Category $\mathrm{C}$ & food and drinks & 3210452 & $31.41 \%$ & 63 \\
\hline Category D & textile, clothing, leather, shoes & 156143 & $1.53 \%$ & 3 \\
\hline Category E & $\begin{array}{l}\text { other manufacturing industry (electrical devices, pharmaceutical } \\
\text { products, chemicals and chemical products, motor vehicles, } \\
\text { furniture, other products, computers, electronic and optical } \\
\text { products) }\end{array}$ & 4726769 & $46.25 \%$ & 93 \\
\hline Category L & information and communication activities & 977682 & $9.57 \%$ & 19 \\
\hline Category M & finance and insurance & 737169 & $7.21 \%$ & 14 \\
\hline \multirow[t]{2}{*}{ Category $\mathrm{T}$} & cultural, amusement and recreation activities & 412888 & $4.04 \%$ & 8 \\
\hline & Total in C, D, E, L, M, T & 10221103 & $100 \%$ & 200 \\
\hline
\end{tabular}

Your Image



Color Map



Figure 1 Example of the software transformation: Bepanthen Care's Barcode and Color Map (Source: MulticolorEngine [24])

was conducted. However, the p-value $=0.967$ (Pearson Chi-Square = 33.226; $\mathrm{df}=50)$ indicates that $\mathrm{H}_{0}$ cannot be rejected. There is no statistically significant difference between the categories in the usage of colors.

Since neutral colors are often used as a background color to emphasize the objects or messages in the foreground, we skipped the neutral colors and conducted the Chi-Square Test of Independence again. However, even with the neutral colors removed, there was no statistically significant difference among the categories in the usage of colors ( $\mathrm{p}$-value $=1.000$; Pearson ChiSquare $=13.605 ; \mathrm{df}=35)$. Therefore, the $\mathrm{H}_{0}$ cannot be rejected.

Table 4 provides a similar analysis as above; however, it distinguishes only between neutral-cool-warm groups of colors.

Again, in some categories (D, M, L), the neutral colors were the most prominent. The cool colors were the most used only in $\mathrm{T}$, while the warm colors were the predominant only in $\mathrm{C}$. The Chi-Square Test of Independence once more revealed there is no statistically significant difference among categories in the usage of colors ( $\mathrm{p}$-value $=0.400$; Pearson Chi-Square $=10.478 ; \mathrm{df}=10$ ). Similarly to the previous analyses, the $\mathrm{H}_{0}$ cannot be rejected.

\section{Discussion}

The analysis revealed no statistically significant difference in the usage of colors among the most frequently represented categories of video adverts in the Czech Republic in 2016. However, this does not mean that the advertisers in the Czech Republic do not follow the color theories addressing the color scheme recommendations for different product categories.

The popularity of using neutral colors (esp. gray) can be explained by the fact that the background is usually colored with a neutral color to highlight the object of the communicated message (product, service, or message) [26, 27]. The background is monochrome and represents the largest space of a scene. The results also resonate with previous studies (i.e. [11]) suggesting that cool colors are used more often than the warm ones.

Category $C$ (food and drinks) is the only category which has more than $13 \%$ brown $(30.74 \%)$. Brown is associated with nature [5] and environmental quality [19]. Other colors associated with healthy food are blue (12.36\%), green (15.34\%) and yellow [16]. Therefore, the colors used to promote companies and their products and services in this category generally follow the recommendations about proper color scheme choice. 
Table 2 Color usage in TV commercials

\begin{tabular}{|c|c|c|c|c|c|c|c|c|c|c|c|}
\hline Hue & 岕 & 言 & $\stackrel{\mathscr{D}}{\Xi}$ & $\begin{array}{l}\text { ญี } \\
\text { ठँ }\end{array}$ & $\frac{\frac{y}{0}}{\tilde{J}}$ & $\stackrel{\stackrel{\mathscr{Z}}{3}}{3}$ & $\frac{\stackrel{ \pm}{\circ}}{\stackrel{>}{>}}$ & $\underset{\mathbb{Z}}{\mathscr{Z}}$ & $\frac{z}{\bar{d}}$ & 当 & 范 \\
\hline Percentage & 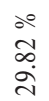 & $\begin{array}{l}\stackrel{0}{0} \\
\stackrel{\infty}{0}\end{array}$ & $\begin{array}{l}\text { de } \\
\text { jo } \\
\text { d. }\end{array}$ & 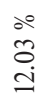 & $\begin{array}{l}\text { je } \\
\text { E } \\
=\end{array}$ & $\frac{\partial 0}{i}$ & $\begin{array}{l}\text { do } \\
\text { 華 } \\
\text { vi }\end{array}$ & $\frac{d 0}{\text { స̃ }}$ & $\begin{array}{l}\text { de } \\
\infty \\
\curvearrowleft\end{array}$ & $\begin{array}{l}20 \\
6 \\
0\end{array}$ & $\begin{array}{l}\text { oீ } \\
\stackrel{\infty}{+}\end{array}$ \\
\hline
\end{tabular}

Table 3 Color share in particular categories

\begin{tabular}{|c|c|c|c|c|c|c|}
\hline & Category C & Category D & Category E & Category L & Category M & Category $\mathrm{T}$ \\
\hline 1. & Brown (30.74 \%) & Gray (60.17 \%) & Gray (31.05 \%) & Gray (34.44 \%) & Gray (42.28 \%) & Blue (35.31 \%) \\
\hline 2. & Gray (24.47 \%) & Blue (12.60 \%) & Blue (18.48 \%) & Blue (16.64 \%) & Black (12.77 \%) & Black (27.49 \%) \\
\hline 3. & Green (15.34 \%) & Brown (12.30 \%) & Brown (12.93\%) & Black (14.41 \%) & Blue (11.32 \%) & Gray (13.39 \%) \\
\hline 4. & Blue (12.36 \%) & White $(5.63 \%)$ & Black (11.32 \%) & Brown (11.66 \%) & Brown (10.47 \%) & Brown (10.11 \%) \\
\hline 5. & Black $(9.85 \%)$ & Green $(5.20 \%)$ & Green (10.92\%) & Green (10.97 \%) & Green $(9.62 \%)$ & Green $(8.29 \%)$ \\
\hline 6. & Violet (2.83 \%) & Black (2.43 \%) & White (6.43\%) & Violet (5.35 \%) & White $(5.04 \%)$ & Violet $(2.86 \%)$ \\
\hline 7. & Yellow (2.08 \%) & Violet (1.47 \%) & $\operatorname{Red}(3.09 \%)$ & White (2.36 \%) & $\operatorname{Red}(2.52 \%)$ & Yellow $(1.26 \%)$ \\
\hline 8. & $\operatorname{Red}(1.56 \%)$ & Pink $(0.13 \%)$ & Violet (1.98 \%) & Yellow ( 1.83 \%) & Yellow (1.98 \%) & White $(0.98 \%)$ \\
\hline 9. & Orange $(0.37 \%)$ & - & Yellow (1.22 \%) & $\operatorname{Red}(1.63 \%)$ & Violet (1.20\%) & $\operatorname{Red}(0.21 \%)$ \\
\hline 10. & Pink $(0.35 \%)$ & - & Pink (1.05 \%) & Pink $(0.51 \%)$ & Orange $(0.98 \%)$ & Pink (0.05\%) \\
\hline 11. & White $(0.05 \%)$ & - & Orange $(0.63 \%)$ & Orange $(0.02 \%)$ & - & - \\
\hline
\end{tabular}

Surprisingly more than half the share of Category D (textile, clothing, leather, shoes) is devoted to one color (60.17\%; gray) and exhibits less basic colors than the other categories (only 8). As clothing is a product of low involvement [3], the reason for using mostly gray may lie in the customers' color preferences. As the individual color preferences play a prominent role in the purchase decision, in this product category it can be hazardous to choose a specific color. There is no universal or generally accepted color for such products; therefore, the advertisers could use a neutral color deliberately. Moreover, cool and warm colors are balanced in this category.

Category $E$ (other manufacturing industry) is also mostly represented by a neutral color ( $31.05 \%$; gray), which is probably due to highlighting the object of the communicated message in the foreground. The other most frequently represented colors reflect the nature of the products in this category - blue $(18.48 \%)$ and green $(10.92 \%)$ are appropriate colors for functional products [1].

The results of Category L (information and communication activities) and Category $M$ (finance and insurance) are similar to Category E. The prevailing colors are neutral - gray (34.44\% for L, $42.28 \%$ for M), followed by black ( $14.41 \%$ for L; $12.77 \%$ for M). The neutral colors are followed by blue ( $16.64 \%$ for L; 11.32 $\%$ for $\mathrm{M}$ ) and green ( $10.97 \%$ for $\mathrm{L}, 9.62 \%$ for $\mathrm{M}$ ), which are typical for functional products [1]. What is quite surprising is the higher share of brown ( $11.66 \%$ for L; $10.47 \%$ for M). However, information and communication technologies, as well as the financial product, are often shown as contributing to a better environment and the quality of life these days [28, 29]. Again, it can be concluded that the prevailing colors reflect the nature of the products from these categories.

Surprisingly Category $T$ (cultural, amusement and recreation activities) is represented by the higher share of blue (and therefore cool) color (35.31\%), followed by black (27.49\%) and gray ( $13.39 \%)$. Such products were expected to be promoted with bright and warm colors expressing pleasure or social approval [1]. Contrary to this, red $(0.21 \%)$, yellow ( $1.26 \%)$, and violet $(2.86 \%)$ represent less than $5 \%$ of the share of colors used in the video adverts. The advertisers do not follow the general recommendations for this category.

\section{Conclusion}

This study aimed to analyze the differences in color schemes in TV commercials across different product categories. The research sample was 200 video adverts aired in the Czech Republic in 2016. The adverts came from the largest advertisers in the country in product categories representing over $90 \%$ of all aired advertisements. Even if the analysis revealed no statistically significant difference in the usage of colors among the most frequently represented categories, it still provided some interesting conclusions.

Surprisingly, the most used colors are neutral (especially gray and black). The other colors generally reflect the recommendations for using colors in marketing communications 
Table 4 Color groups share in particular categories

\begin{tabular}{ccccccc}
\hline & Category C & Category D & Category E & Category L & Category M & Category T \\
\hline Neutral & $34.37 \%$ & $68.28 \%$ & $49.24 \%$ & $51.30 \%$ & $61.20 \%$ & $41.88 \%$ \\
Cool & $30.53 \%$ & $19.28 \%$ & $31.66 \%$ & $33.02 \%$ & $22.55 \%$ & $46.48 \%$ \\
Warm & $35.10 \%$ & $12.44 \%$ & $19.09 \%$ & $15.68 \%$ & $16.25 \%$ & $11.64 \%$ \\
\hline
\end{tabular}

and the psychological properties of colors. The findings are in line with previous empirical studies and contribute to the field by providing additional empirical evidence. Moreover, there are only limited studies in Central Europe area in this field.

Our study also provides some managerial implications. It emphasizes the role of colors in marketing communication in the mass media and provides an overview of the Czech advertising market. The marketers should carefully design their marketing campaigns with respect to consumer color preferences in particular categories [7]. Some studies suggest the color scheme or composition plays an important role in perceiving the gist of the communicated message [30]. On the other hand, a successful marketing strategy also requires to step out of the crowd and not to blindly follow the routine and general color recommendations. The colors preferences, perceptions, or associations are prone to cultural bias [31], even though some studies suggest the color effects operate on universal levels as well [7]. Managers definitely need a deeper insight into the psychological effects of colors in marketing, esp. in the international environment where it remains a challenge to find a balance between establishing and maintaining a product image and reflecting consumers' cultural backgrounds.

There are several limitations of this study. The research sample of 200 commercials accounts for only $0.1 \%$ of the total number (195 306) of all unique commercials broadcast in the Czech Republic in 2016. The results are also biased by the selection (even though it was random) of adverts and an extended study is needed. Color research is also prone to perceptual and cultural bias - i.e. different people have a different perception of colors (according to their physical conditions and limitations), the lighting of the environment influences the color perception, and colors have various meanings in different cultures. Therefore, the conclusions of this study must be considered with respect to its limitations.

The limitations of this study also provide an opportunity for further research. The study could be extended in terms of research sample size (even though the processing of the adverts is being made manually and is time-consuming) and could also cover more product categories. The differences between various national markets also call for a deeper investigation.

\section{Acknowledgements}

This research was supported by the Internal Grant Agency project F6/5/2017. The authors thank Michal Novak and Vladislav Bina (University of Economics, Prague) for their useful suggestions.

\section{References}

[1] BOTTOMLEY, P. A., DOYLE, J. R.: The Interactive Effects of Colors and Products on Perceptions of Brand Logo Appropriateness. Marketing Theory, 6(1), 63-83, 2006.

[2] GARBER, L. L., BURKE, R., JONES, J.: The Role of Package Color in Consumer Purchase Consideration and Choice (working paper). Marketing Science Institute, Cambridge, 2000.

[3] GROSSMAN, R. P., WISENBLIT, J. Z.: What We Know about Consumers' Color Choices. Journal of Marketing Practice: Applied Marketing Science, 5(3), 78-88, 1999.

[4] CYR, D., HEAD, M., LARIOS, H.: Color Appeal in Website Design within and across Cultures: A Multi-Method Evaluation. International Journal of Human-Computer Studies, 68(1), 1-21, 2010.

[5] LABRECQUE, L. I., MILNE, G. R.: Exciting Red and Competent Blue: The Importance of Color in Marketing. Journal of the Academy of Marketing Science, 40(5), 711-727, 2012.

[6] LEE, T. R., TANG, D. L., TSAI, C. M.: Exploring Color Preference through Eye Tracking. AIC Color 05 - 10th Congress of the International Color Association, 3(5), 333-336, 2005.

[7] GORN, G. J., CHATTOPADHYAY, A., YI, T., DAHL, D. W.: Effects of Color as an Executional Cue in Advertising: They're in the Shade. Management Science, 43(10), 1387-1400, 1997.

[8] GROBELNY, J., MICHALSKI, R.: The Role of Background Color, Interletter Spacing, and Font Size on Preferences in the Digital Presentation of a Product. Computers in Human Behavior, 43, 85-100, 2015.

[9] SINGH, S.: Impact of Color on Marketing. Management Decision, 44(6), 783-789, 2006. 
[10] HUANG, J. H.: Color in US and Taiwanese Industrial Advertising. Industrial Marketing Management, 22(3), 195-198, 1993.

[11] CROWLEY, A. E.: The Two-Dimensional Impact of Color on Shopping. Marketing Letters, 4(1), 59-69, 1993.

[12] VALDEZ, P., MEHRABIAN, A.: Effects of Color on Emotions. Journal of Experimental Psychology: General, 123(4), 394-409, 1994.

[13] LUSCHER, M.: The Luscher Color Test. Simon and Schuster, New York, 1969.

[14] PAGE, T., THORSTEINSSON, G., HA, J. G.: Using Colors to Alter Consumer Behaviour and Product Success. International Journal of Contents, 8(1), 69-73, 2012.

[15] WEDEL, M., PIETERS, R.: The Buffer Effect: The Role of Color when Advertising Exposures are Brief and Blurred. Marketing Science, 34(1), 134-143, 2014.

[16] ASLAM, M. M.: Are You Selling the Right Color? A Cross-Cultural Review of Color as a Marketing Cue. Journal of Marketing Communications, 12(1), 15-30, 2006.

[17] FERNANDEZ, K. V., ROSEN, D. L.:. The Effectiveness of Information and Color in Yellow Pages Advertising. Journal of Advertising, 29(2), 61-73, 2000.

[18] PEleT, J. E., CONWAY, C. M., PAPADOPOUloU, P., LIMAYEM, M.: Chromatic Scales on Our Eyes: How User Trust in a Website Can Be Altered by Color via Emotion. Benghozi, P. J., Krob, D., Rowe, F. (Ed.): Digital Enterprise Design and Management. Springer, Berlin Heidelberg, 2013.

[19] SINGH, N., SRIVASTAVA, S. K.: Impact of Colors on the Psychology of Marketing - A Comprehensive over View. Management and Labour Studies, 36(2), 199-209, 2011.

[20] GRITTEN, A.: Forum - Media Proliferation and the Demand for New Forms of Research. Journal of the Market Research Society, 49(1), 15-23, 2007.

[21] TAYLOR, C. R., BONNER, G. P., DOLEZAL, M.: Advertising in the Czech Republic: Czech Perceptions of Effective Advertising and Advertising Clutter. Taylor C. R. (Ed.): New Directions in International Advertising Research. Emerald Group Publishing Limited, UK, 2002.

[22] NOVAK, M., KINCL, T., LUSTICKY, M.: Industry Analysis of TV Commercials: Do Companies Reflect Audience Profiles? Journal of Direct, Data and Digital Marketing Practice, 17(3), 187-200, 2016.

[23] LAILY, M.: Movie Barcode Generator, version 0.5 [online]. 2013. Available: http://arcanesanctum.net/movie-barcode-generator (accessed 2017-05-23).

[24] MULTICOLORENGINE: Color Extraction [online]. 2017. Available: http://labs.tineye.com/color (accessed 2017-05-25).

[25] BERLIN, B., KAY, P.: Basic Color Terms: Their Universality and Evolution. University of California Press, Berkeley, 1969.

[26] BROWN, R. O., MACLEOD, D. I.: Color Appearance Depends on the Variance of Surround Colors. Current Biology, 7(11), 844-849, 1997.

[27] FARLEY, J.: Color in Design: Gray [online]. 2010. Available: https://www.sitepoint.com/color-in-design-grey (accessed 2017-06$15)$.

[28] Cradle to Cradle Products Innovation Institute: The Role of Financial Institutions in Sustainable Building [online]. 2017. Available: http://www.c2ccertified.org/news/article/the-role-of-financial-institutions-in-sustainable-building (accessed 2017-06-15).

[29] PYMNTS: Banking on Socially Conscious Consumers [online]. 2017. Available: http://www.pymnts.com/news/digitalbanking/2017/digital-banking-tracker-socially-conscious-consumers-seek-sustainable-banking (accessed 2017-03-27).

[30] WEDEL, M., PIETERS, R.: The Buffer Effect: The Role of Color When Advertising Axposures Are Brief and Blurred. Marketing Science, 34(1), 134-143, 2014.

[31] MADDEN, T. J., HEWETT, K., ROTH, M. S.: Managing Images in Different Cultures: A Cross-National Study of Color Meanings and Preferences. Journal of International Marketing, 8(4), 90-107, 2000. 
Appendix A - List of Analyzed Advertisements

\begin{tabular}{lll}
\hline & \multicolumn{1}{c}{ Category C } & \\
\hline 7 Days - Euroleague & Hello - Vybirejte srdcem & Milkana - Chut plna mleka \\
Ahmad Tea - Ledove caje & HiPP - Nic neni bliz materskemu mleku & Milko - Recke jogurty zimni limitovana edice \\
Algida - Porce rodinne radosti & Chio Chips - Pritahnou kazdeho & Mlekarna Kunin - President \\
Aperol Spritz - Naladi po praci & Chocenska mlekarna - Jalapeno Poctive palive & Nestea - Udelej pro sebe neco dobreho \\
Aquila - Prvni voda AquaBabes & Chupa Chups - Doba ledova 5 & Nestle - Cheerios Oats \\
Babiccina volba - Dortova Velikonoce & Jacobs - Snete s otevrenyma ocima & Orbit - Jezte, pijte, zvykejte \\
BeBe dobre rano - Namekko Energie na Cele & Jupi - Fousate leto & Pedigree - Denta Stix \\
dopoledne & Kinder Bueno - Orient Express & Pickwick - Zahreje nejen vase telo, ale i dusi \\
Becherovka Original - Cim vetsi vasen, tim & Kofola - Fofola a couvani & Pilsner Urquell - Svetlo Vanoc \\
vetsi radost & Kostelecke uzeniny - Poctive parky z Kostelce & Prima - Mroz zmrzlina vyrobena s laskou \\
Bertolli - To nejlepsi z masla a olivoveho oleje & Lays - Pivo chutna lepe s Lays strong & Purina ONE - 3 tydenni test \\
Big Corny - Corny to das! & Lindt - Lindor Tajemstvi & Rajec - Patentovane prirodou \\
Big Shock - Sokuj sam sebe & Lucina - Nadychana s okurkou a koprem & Sedlcansky - Soutez nozik \\
Bohemia Chips - Soutez o pekacky & M\&Ms - Sam si vlez do misky & Semtex - Odpal to naplno \\
Bozkov - Bozkov bily & Maggi - Extra silny bujon & Staropramen - Jedno nas spojuje \\
Brit - Let's bite! & Majka - Radost byt spolu & Sunar - Po kom to ma? Po Sunaru. \\
Coca Cola - Vanoce 2016 & Mattoni - Pomerancove mambo & Tatra - mlsani, ktere neomrzi \\
Danone - Activia & Merci - Finest Selection & Tic Tac - Osvezujici chvile \\
Dr Oetker - Paula strakaty puding & Milka - Kouzlo Vanoc kazdy den & Tuc - Vitejte v zemi moznosti \\
Emco - Mamy dekujeme & & Vinarske fondy - Na zivot jako vino! \\
Fanta - Fantasticka zabava & & Vitana - Farmarske polevky \\
Frisco - Objevte nove barvy noci s Frisco & & Zott - Monte Snack \\
Night & & \\
Granko - retro edice & & \\
Hellmanns - Delikatni tatarska omacka & & \\
\hline
\end{tabular}

\begin{tabular}{lll}
\hline & \multicolumn{1}{c}{ Category D } & \\
\hline Deichmann - jaro leto 2016 & Dormeo - Fresh Prima & \multicolumn{1}{c}{ Category E } \\
\hline & \multicolumn{1}{c}{ F\&F - leto 2016 } \\
\hline Airwick - Wax Melt vune domova & Ford - Tuhle jizdu si urcite zaslouzite. & Nicorette - Zbavte se zavislosti na koureni \\
Albi - iKnow & Garnier - Velka show s Benem Cristovaoem & Nissan - Stvoren pro rodinu. \\
Ariel - Velka vyzva „Ariel“ cistota & Gorenje - Design by Starck & Nivea - Krasne vlasy diky peci Nivea. \\
Audi - Q2 \#untaggable. Naskok diky technice. & Grand Optical - 3 bryle za cenu 1 & Olynth - Uvolnuje, zvlhcuje a regeneruje \\
Avon - Nutra Effects rozjasnujici krem, krasne & Hamleys - Zabava zacina. & Oral-B - Stante se expertem s Oral-B \\
pro sebe & Herbadent - Vychytavky Extra & Oriflame - Oriflame Sweden \\
Balakryl - Voskovy olej & Honore - Eva Samkova. Zapomen na pochyby. & Oscillococcinum - Preventivne a od prvnich \\
Bepanthen Care - ucinna pece proti projevum & Huawei - Jaromir Jagr. Make it Possible & priznaku \\
opruzeni miminek & Hugo Boss - The Scent & Pampers - Tak suche, kam se to vsak podelo? \\
Blackfire - Svet her a zabavy. & Hylak Forte - Pro Vase traveni jako nove & Paralen - Oblibena klasika na horecku a bolest. \\
BMW - Radost z jizdy. & Hyundai - Sebejisty za vsech okolnosti & Parodontax - Pomaha zastavit a predchazet \\
Borotalco - Stop poceni & Ibalgin gel - Natrete to bolesti & krvaceni dasni \\
Bosch - Silent Mixx prislusenstvi & Igracek - Jsi cesky original, jsi Igracek. & Persil - Deti kuji pikle \\
Braun - Jessica Alba & Indulona - vsestranna pece & Peugeot - Nove SUV Peugeot \\
Buxton - Buxton & InSportline - domaci posilovna & Pompo - katalog. Sileny profesor. \\
Calvin Klein - Deep Euphoria & Isana - Sprchovy gel pro zeny nebo pro muze & Priessnitz - Priessnitz \\
Cannaderm - Mentholka Extra & Kia - Zcela nova Sportage. & Primalex - Vymalujte si zivot \\
Citroen - Angry Birds & Kika - Domov vaseho zivota. & Rimmel - Neprekonatelna Cara Delevingne. \\
Clavin - kolo & & Rimmel London. \\
& &
\end{tabular}


Coldrex - Silnejsi nez chripka a nachlazeni

Colgate - Objev ji pro sebe

Corega - Jezte, mluvte a smejte se s jistotou!

Dacia - Zase dalsi ridi Duster

Dedra - Dedra Innovations primo k Vam.

Dermacol - 16H Lip Colour. Pro lasku jako stvorena.

Dolgit - pomaha pri artroze a revmatismu

Doliva - rada s olivovym olejem

Domestos - Sila v kazdem splachnuti

Dove - Moje vlasy moje volba

Durex - Mene casu s displejem vice casu na hrani

Espumisan - Simeticonum 40mg

Festina - Time to live.

Fiat - Nalad se na X.

Fisher Price - Smej se a poznavej!
Klenoty Aurum - Jaromir Jagr. Sperky nejsou hrich.

Lacalut - zubni pasta, ktera ucinkuje

Lactacyd - Protoze sebeduvera je videt.

Lancome - Zivot je krasny. Vune stesti

Lenor - Amy Sedaris Unstoppables

LG - Nejlepsi televize vsech dob

Lioton - Pro Vase zdravi a krasu

Listerine - Pocit v sobe silu

Loreal - Excellence Creme, Vy za to stojite.

Martanci - Vesmirny projektor

Mixa - Cold Cream. I citliva plet si zaslouzi hyckat.

Mobelix - To nejlepsi pouze vyhodneji.

MoliMed - O krok dal pro zdravi
Sally Hansen - Sally Hansen

Savo - Bezchlorova rada. Resi temer kazdy problem v domacnosti.

Sensodyne - Zubni lekari doporucuji Sensodyne.

Septabene - v krku vase sila

Sikaflex - Stavime na duvere

Somat - Tak ciste. Tak snadne

Spektrum - Spektrum Gummies

Surf - Vune cisteho pradla

Varilux - Dej silu svemu videni.

Vicks - Od nachlazeni zpet k zivotu.

Vichy - Cas leti, ale vy muzete zpomalit.

Volkswagen - Dokonalost je jen zacatek.

Wobenzym - ...proste pomaha

Zendium - Podporujte prirozenou obranyschopnost Vasi ustni dutiny.

\begin{tabular}{|c|c|c|}
\hline \multicolumn{3}{|c|}{ Category L } \\
\hline $\begin{array}{l}\text { Casopis Epocha - Casopis, ktery Vas vtahne } \\
\text { do deje. }\end{array}$ & $\begin{array}{l}\text { Fortuna - Trezor. } 100 \mathrm{Kc} \text { na ruku pro nove } \\
\text { hrace. }\end{array}$ & $\begin{array}{l}\text { Muj cas na kaficko - To nejlepsi, co si muzete } \\
\text { ke kave dat. }\end{array}$ \\
\hline Cedok - Verite nam od roku 1920. & Frekvence 1 - Hraje nase pisnicky. & Muj svet - Zivot, ktery me bavi. \\
\hline Denik Metro - Vase metropolitni noviny. & Invia - More zajezdu na jednom miste. & Neckermann - Budte drzi. \\
\hline DIGI - Nova DIGI TV & Mapy - Mobilni aplikace Mapy.cz & O2 - Nadelujeme to nejlepsi z chytre site \\
\hline E-darling - Seznamka pro narocne. & Moje chvilka pohody - Casopis, co Vas chytne & T-mobile - Klinika inovativni pece \\
\hline Exim Tours - Poradatel cest do exotickych & za srdce. & UPC - Bez zpomalovani a vypadku \\
\hline raju & Moje stastna hvezda - Naladte se do pohody. & Vodafone - Probudte v sobe to nejlepsi \\
\hline \multicolumn{3}{|c|}{ Category M } \\
\hline Airbank - I banku muzete mit radi. & CSOB - Investice pro kazdeho & \multirow{2}{*}{$\begin{array}{l}\text { Sberbank - Fer pujcka srpen 2016. Vas pribeh, } \\
\text { Vase banka. }\end{array}$} \\
\hline Allianz - Revoluce v autopojisteni & Equa bank - Repujcka & \\
\hline Cetelem - $200000 \mathrm{Kc}$ za $2700 \mathrm{Kc}$ mesicne & Fio - Ucet pro obcany, podnikatele i firmy bez & \multirow{5}{*}{$\begin{array}{l}\text { Unicredit bank - Pro vsechny, kdo neprestavaji } \\
\text { chtit vic. } \\
\text { Zlato.cz - Chytre sporeni s Felixem } \\
\text { Zonky - Lide pujcuji lidem. }\end{array}$} \\
\hline Cofidis - Partnerska pujcka. Dik za lasku tvoji & poplatku a podminek & \\
\hline zlato. & ING - Podilove fondy. Penize na spravnem & \\
\hline Creditas - Chtejte vic od svych uspor. & miste. & \\
\hline & Mastercard - Priceless Specials & \\
\hline \multicolumn{3}{|c|}{ Category $\mathrm{T}$} \\
\hline Adademie ved CR - Tyden vedy a techniky. & Cinema City - 1. kvetna 2016 & Red Bull - Red Bull Flying Bach \\
\hline $\begin{array}{l}\text { Aqualand Moravia - Nejvetsi zabava pod } \\
\text { sluncem }\end{array}$ & $\begin{array}{l}\text { CZECH TEAM - Vsichni jsme jeden tym. } \\
\text { Eurojackpot - Pravy duch Vanoc }\end{array}$ & Tipsport - Vstupte do nejvetsi komunity sazkaru \\
\hline Cine Star - Cool Ticket & & \\
\hline
\end{tabular}

